\title{
Enhanced Performance of an Integrated Pyroelectric Infrared Detector on a Flexible Substrate: Modeling and Simulation
}

\author{
Alakananda Bandyopadhyay ${ }^{1}$, K.J. Arun ${ }^{2,3, *}$, Ashok Batra ${ }^{2, \dagger}$, Mohan Aggarwal $^{2}$ \\ ${ }^{1}$ Department of Electrical Engineering \& Computer Science, Alabama A\&M University, 35762 Alabama, USA \\ 2 Department of Physics, Chemistry, and Mathematics, Alabama A\&M University Normal, 35762 Alabama, USA \\ ${ }^{3}$ Department of Physics, Sree Kerala Varma College, Thrissur, 680011 Kerala, India
}

(Received 14 August 2020; revised manuscript received 15 December 2020; published online 25 December 2020)

\begin{abstract}
The sensitivity and performance of an integrated pyroelectric infrared detector depend not only on the material characteristics of a sensor element, but also on the thermal performance of the complete structure of detector design, including associated electronics. Thus, we have derived the thermal transfer function by solving the one-dimensional thermal diffusion equation for a single element $n$-layer structure, from which the performance of the detector structure of any number of layers can be obtained, predicted and optimized. Various single sensor configurations on the flexible substrate, polyimide, and pyroelectric and thermal parameters of modified lead strontium titanate (PST) film are utilized to predict the current responsivity of an integrated detector system. The results obtained are compared with silicon as a substrate and found to be attractive for the development of a flexible thin-film based detector system.
\end{abstract}

Keywords: Pyroelectric, Infrared detectors, PST, Polyimide, MatLab Version 9.0.

DOI: 10.21272/jnep.12(6).06007

PACS numbers: 07.05.Tp, 85.50._n, 07.57.Kp

\section{INTRODUCTION}

Recently, the field of flexible electronics has made enormous progress [1]. Demand for uncooled infrared (IR) sensors is increasing in many applications such as automobile, biomedical, plant monitoring, security system, various military applications [2]. Pyroelectric IR detectors offer an advantage of room-temperature operation and a broad spectral response. For these applications, efforts have been made to develop uncooled IR and imaging devices. As a result of these efforts, the use of high-performance crystalline ferroelectrics, such as triglycine sulfate (TGS), polyvinylidene fluoride (PVDF), lead strontium titanate (PST), strontium barium niobate (SBN), lithium tantalate (LT), and ferroelectric perovskite ceramics have been developed [3-5].

Nevertheless, it is still required to enhance the performance of the pyroelectric materials and to integrate pyroelectric films into linear and $2 \mathrm{D}$ arrays, which can further improve their performance and applicability by compatibility with organic electronics. Efforts have been made in this direction, to deposit pyroelectric films on silicon and other substrates [6-12]. The rising concern is about the effect of substrate thickness on the efficiency of pyroelectric sensors. There have been several theoretical and experimental investigations on the effect of the substrate on the pyroelectric detectors [13-15]. Monolithic pyroelectric detectors have excellent characteristics such as fast response, responsivity, and high detectivity. However, scant studies have been performed on the design of flexible pyroelectric detector on organic material-system such as integrated sensors along with the amplifier using flexible organic technology.

Adequate sensitivity and performance depend not only on the characteristics of the sensor material and associated electronics, but also on the thermal perfor- mance of the complete structure of a detector. In this article, for accurate modeling of a flexible integrated pyroelectric detector, the $n$-layer structure is selected for thermal analysis with flexible polyimide (PI) as a substrate and PST as a pyroelectric element. PI is selected due to its low thermal conductivity and high strength as compared with silicon.

\section{THERMAL ANALYSIS OF AN INTEGRATED DETECTOR SYSTEM}

Thermal analysis is a critical part of the design of thin-film IR detectors. The structure of the detector used in the present thermal analysis is shown in Fig. 1, which consists of $N$ layers. We have assumed that IR radiation is modulated sinusoidally by a mechanical chopper at an angular frequency which falls on the front surface of an absorbing layer and is converted to thermal energy that is then conducted to the bulk of the pyroelectric element. One-dimensional heat conduction equation is employed. An assumption is made whereby the lateral dimensions are considerably larger when compared to the thickness of the composite structure. Lateral heat flow is neglected in the modeling.

The thermal diffusion equation for an $n$-th layer is:

$$
\frac{\partial T_{n}(x, t)}{\partial t}=\frac{K_{n}}{c_{n} \rho_{n}} \frac{\partial^{2} T_{n}(x, t)}{\partial x^{2}}
$$

where $c_{n}$ is the specific heat, $\rho_{n}$ is the density, and $K_{n}$ is the thermal conductivity.

Let $T_{n}(x, t)=T_{n}(x) \exp (j \omega t)$. A solution to heat conduction equation with proper boundary conditions such as heat current density is continuous at each interface:

$$
T_{n}(x)=A_{n} \cosh a_{n}\left(x_{n}-x\right)+B_{n} \sinh a_{n}\left(x-x_{n-1}\right)
$$

\footnotetext{
*drarunkj@gmail.com

† ashobatra@gmail.com
} 
(for $n$-th layer, $x_{n} \geq x \geq x_{n-1}$ ), where $T_{n}(x)$ is the excess temperature above the ambient one in the $n$-th layer at a distance $x_{n}$ measured from the upper surface of each layer, $A_{n}$ and $B_{n}$ are the arbitrary complex constants. Now assuming that the second layer is a pyroelectric layer with thickness $d_{2}$, the spatial average temperature in the pyroelectric layer is calculated as:

$$
\bar{T}(t)=\frac{1}{d_{2}} \int_{x_{1}}^{x_{2}} T_{2}(x, t) d x .
$$

The pyroelectric current $I_{0}$ is

$$
I_{o}=p A \frac{\partial \bar{T}}{\partial t}
$$

where $p$ is the pyroelectric coefficient, and $A$ is the area of the pyroelectric element. The current responsivity is defined as:

$$
R I(\omega)=\frac{j p A \omega \bar{T}}{P}
$$

where $P$ is the incident power. $\bar{T}$ was found out analytically using standard methods and calculated by using Mat Lab Version 9.0 software package.

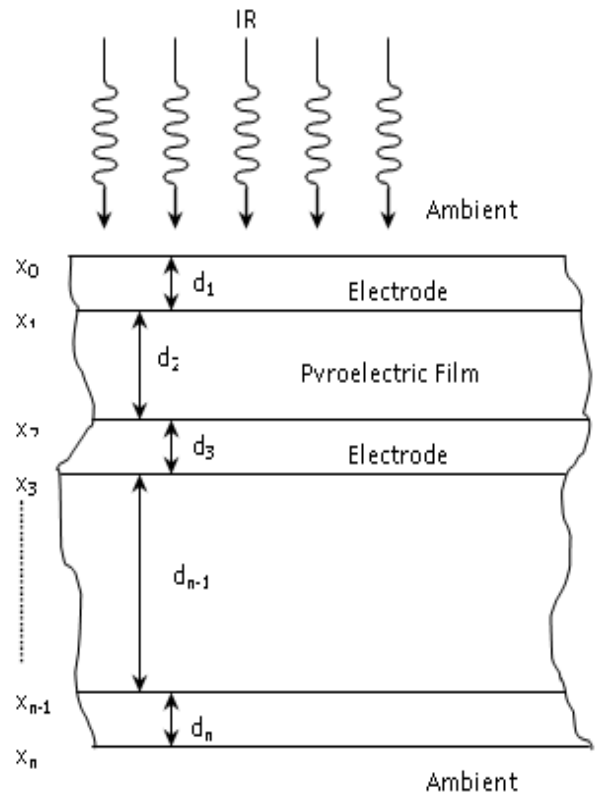

\section{RESULTS AND DISCUSSION}

Using the configuration of the detector system described in Fig. 2 and physical parameters tabulated in Table 1 , the value of the current responsivity $R I(\omega)$ is determined numerically. The value of the pyroelectric coefficient used for PST was taken from the literature.

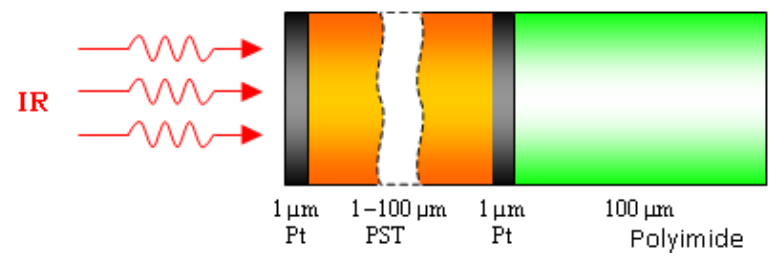

Fig. 2-IR detector cross-section with varying pyroelectric material thickness

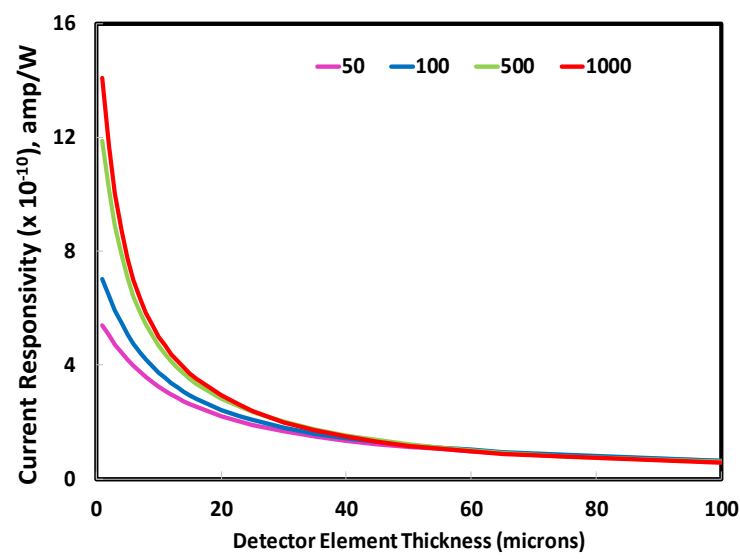

Fig. 3 - Current responsivity (50, 100, 500 and $1000 \mathrm{~Hz}$ ) as a function of detector element thickness with PI substrate

The rest of the parameters are taken from published literature values. Fig. 3 illustrates the effect of the thickness of the pyroelectric PST element on the current responsivity as a function of the chopper frequency on a log-log scale. The thickness of the substrate was assumed to be 100 microns. At a chopping frequency of $100 \mathrm{~Hz}$ with decreasing thickness of PST from 100 microns to 50 microns, there is approximately a four-fold increase in $R I(\omega)$. It suggests that PST thinfilm detectors are of immense value, so efforts should be made to find the ways to fabricate thin films of PST with an optimum thickness and pyroelectric coefficient.

\begin{tabular}{|c|c|c|c|c|}
\hline Material & $\begin{array}{l}\text { Specific heat } \\
(\mathrm{J} / \mathrm{kg} \cdot \mathrm{K})\end{array}$ & $\begin{array}{l}\text { Density } \\
\left(\mathrm{kg} / \mathrm{m}^{3}\right)\end{array}$ & $\begin{array}{c}\text { Thermal } \\
\text { conductivity } \\
(\mathrm{W} / \mathrm{m} \cdot \mathrm{K})\end{array}$ & $\begin{array}{c}\text { Pyroelectric } \\
\text { Coefficient } \\
\left(\mathrm{C}^{\prime} \mathbf{m}^{2} \cdot \mathrm{K}\right)\end{array}$ \\
\hline PST/PZT & 440 & 17700 & 1.45 & 850 \\
\hline $\mathrm{Pt}$ & 134 & 21450 & 69.5 & - \\
\hline $\mathrm{Si}$ & 712 & 2330 & 148 & - \\
\hline PI (Polyimide) & 981 & 1356 & 0.253 & - \\
\hline
\end{tabular}

Fig. 1 - A cross-section of an $n$-layer

Table 1 - Values of parameters used in the current responsivity computation 


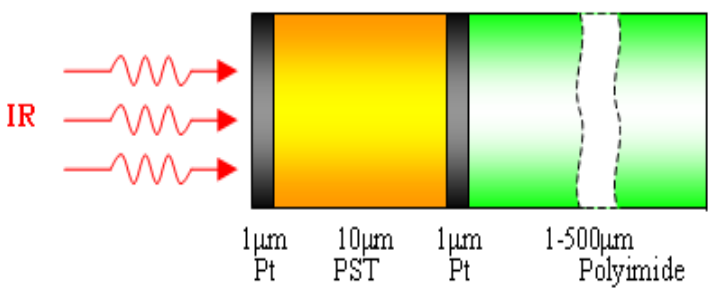

Fig. 4 - IR detector cross-section with varying substrate thickness

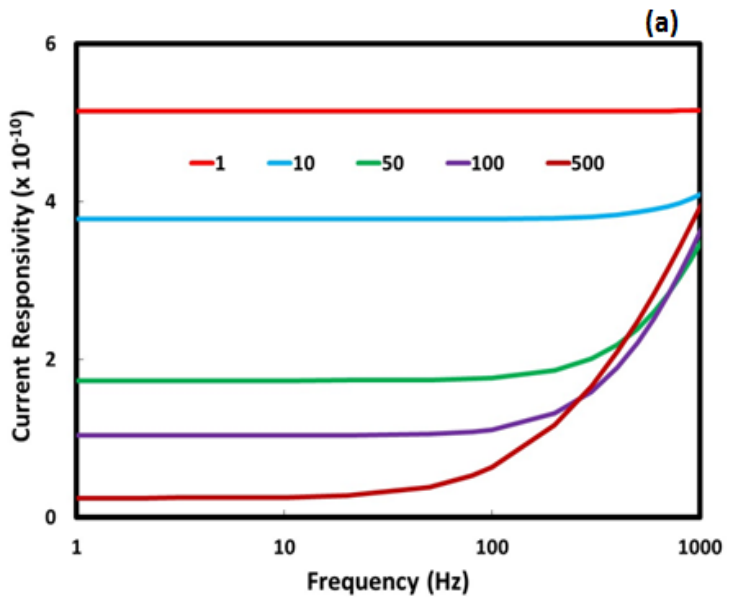

(b)

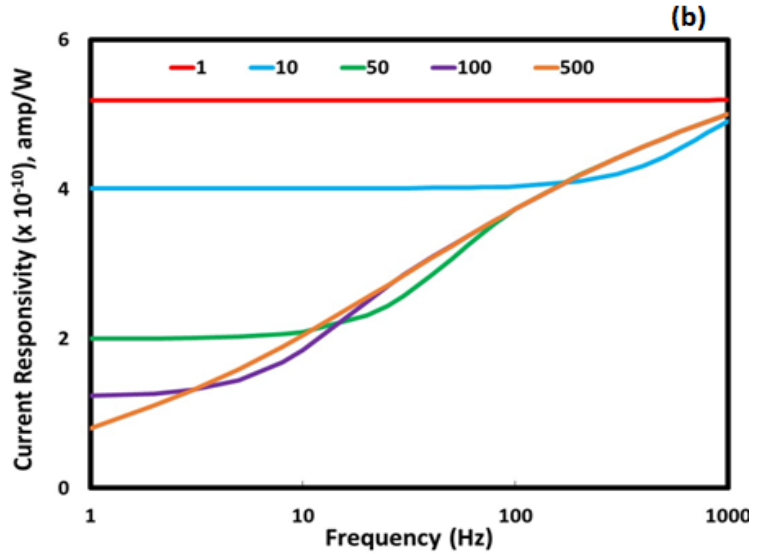

Fig. 5 - Current responsivity as a function of frequency at various substrate thicknesses in microns with (a) Si substrate and (b) PI substrate

The thickness of the pyroelectric element was assumed to be 10 microns. It can be inferred from Fig. 5 at low frequencies, $R I(\omega)$ increases substantially with a decrease in the substrate's thickness. This behavior is because the thinner the substrate, the less the heat in the substrate and hence the higher $R I(\omega)$. Fig. 6 illustrates the difference in $R I(\omega)$ while using Si and flexible PI as a substrate of 100 microns thickness. It can be inferred from Fig. 6 that flexible PI shows higher $R I(\omega)$ in the whole frequency range of practical interest. It is worth mentioning that the use of PI will be very beneficial for integrated flexible electronics applications with the desired amplifier embedded on the PI substrate. Thus, it can further enhance $R I(\omega)$.

The effect of the specific heat value of PI substrate is illustrated in Fig. 7a. The substrate thickness is assumed to be 100 microns and the thermal conductivity of the substrate as that of PI respectively (Fig. 7b).
At lower frequencies, the current responsivity increases with a decrease in the specific heat. However, at higher frequencies the effect of specific heat is not substantial.

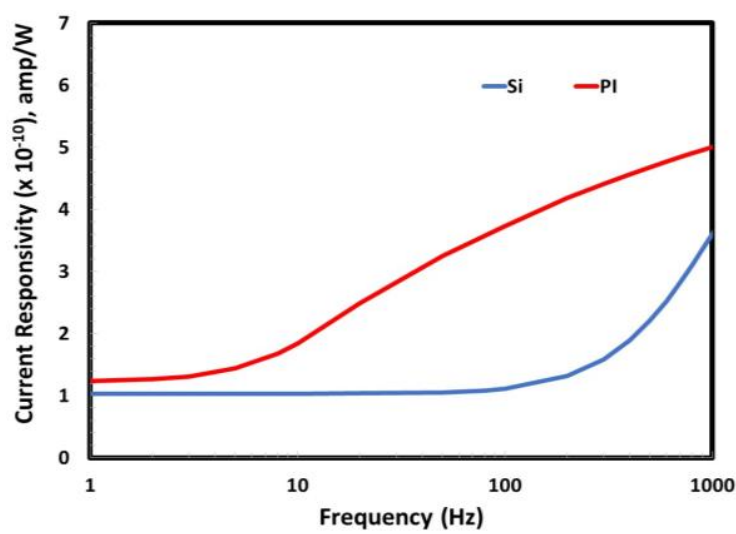

Fig. 6 - Comparison of current responsivity between $\mathrm{Si}$ and PI. The substrate and detector thickness is 100 microns each
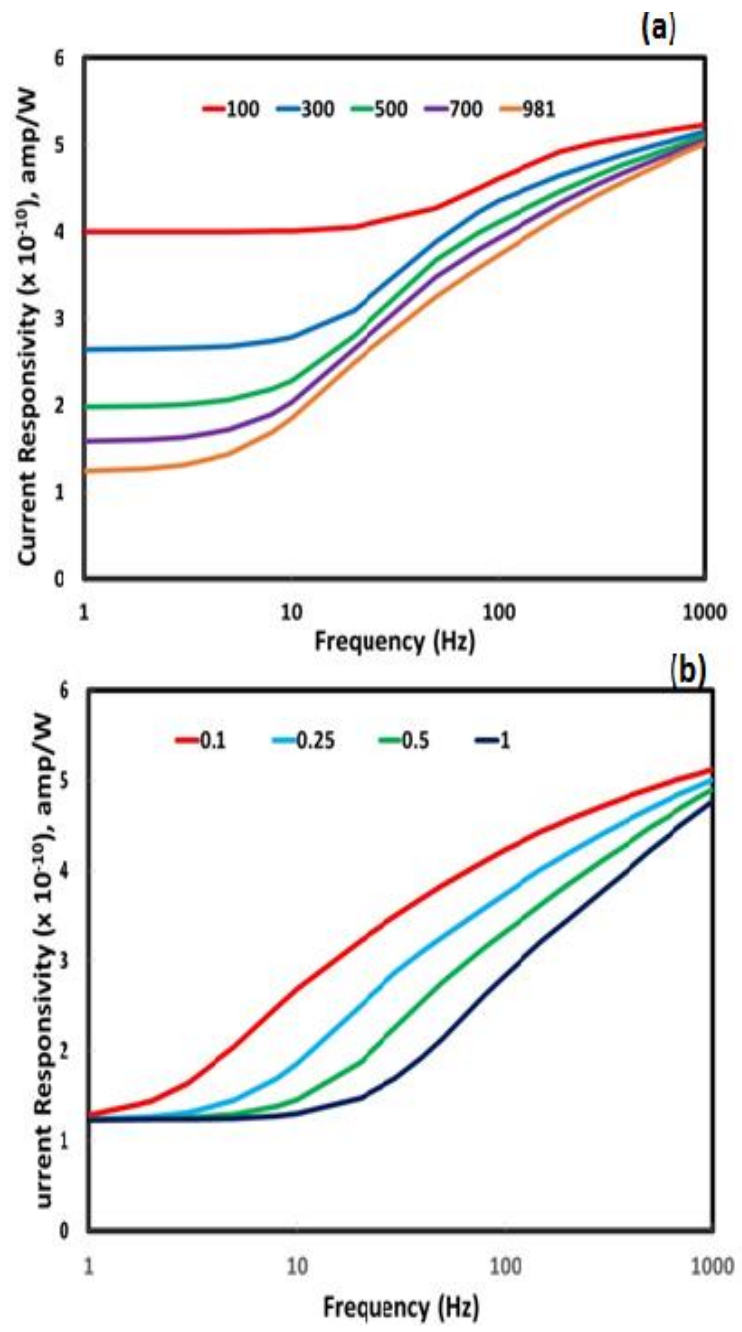

Fig. 7 - Current responsivity with varying (a) specific heat $(\mathrm{J} / \mathrm{kg} \cdot \mathrm{K})$ and $(\mathrm{b})$ thermal conductivity $(\mathrm{W} / \mathrm{m} \cdot \mathrm{K})$ for PI substrate

Fig. $7 \mathrm{~b}$ shows the effect of the substrate's thermal conductivity on the current responsivity with substrate thickness to be 100 microns and specific heat as that of silicon. The higher the thermal conductivity, the lower $R I(\omega)$ at higher frequencies. 


\section{CONCLUSIONS}

(i) The current responsivity of each pyroelectric detector configuration was calculated by solving a onedimensional thermal diffusion equation for a multilayer system.

(ii) Preliminary results indicate that the thicknesses of the pyroelectric crystal and substrate are significant factors, which affect the performance of the detector as illustrated in the figures.

(iii) Furthermore, the introduction of an insulating layer of material PI (polyimide), instead of silicon, enhanced the performance of the pyroelectric detector.

(iv) The algorithms and computer program written in MatLab Version 9.0 are applicable to multi-layer systems with any number of layers. Thus, it facilitates the design of an integrated pyroelectric detector system.

The results obtained are encouraging for the development of a flexible PST thin film-based detector system incorporating amplifier on the same PI substrate. It is expected to reduce the noise component and thus enhance the performance.

\section{ACKNOWLEDGEMENTS}

The authors gratefully acknowledge support for this work through the National Science Foundation grant \#RISE-HRD 1546965. Financial assistance from AAMU-Title III program is appreciated.

\title{
REFERENCES
}

1. Y.S. Rim, S. Bae, H. Chen, N. Marco, Y. Yang, Adv. Mater. 28, 4415 (2016).

2. A. Batra, B. Bohara, J. Mills, R. Wright, B. Kenney, J. Mater. Sci: Mater. Electron. 28, 13336 (2017).

3. A.K. Batra, M.A. Alim, J.R. Currie, M.D. Aggarwal, Physica B 404, 1905 (2009).

4. H. Gould, J. Tobochnik, Computer Simulation Methods. Applications to Physical Systems (New York: AddisonWesley Publishiong: 1988).

5. B. Ploss, S. Bauer, Sensor. Actuat. A 26, 407 (1991).

6. P. Guggilla, A.K. Batra, J.R. Currie, M.D. Aggarwal, M.A. Alim, R.B. Lal, Mater. Lett. 60, 1937 (2006).

7. G. De Cicco, B. Morten, D. Dalmonego, M. Prudenziati, Sensor. Actuat. A 76, 409 (1991).

8. Z. Hongiin, R. Tianling, Z. Ningxin, Z. Ruzhong, W. Xiaohui, L. Litian, L. Zhijian, G. Zhilun, L. Longtu, Mater. Sci. Eng. B 99, 192 (2003).

9. L. Shaobo, L. Yanqiu, J. Mater. Sci.: Mater. Electron. 15, 545 (2004).

10. K.K. Deb, T. Tamagawa, Y. Di, G. Gui, B.L. Halpern, J.J. Schmitt, J. Electron. Mater. 30, 89 (2001).

11. J.S. Ko, W. Liu, W. Zhu, B.M. Kwak, Solid-State Electron. 46, 1155 (2002).

12. L. Jinhua, Y. Ningyi, H.L.W. Chan, Sensor. Actuat. A 100, 231 (2002).

13. A. Pecora, L. Maiolo, F. Maita, A. Minotti, Sensor. Actuat. A 185, 39 (2012).

14. Y. Wang, W. Zhong, P. Zhang, J. Appl. Phys. 74, 521 (1993).

15. R.A. Dorey, R.W. Whatmore, J. Eur. Ceram. Soc. 25, 2379 (2005).

\section{Покращена продуктивність інтегрованого піроелектричного інфрачервоного детектора на гнучкій підкладці: моделювання та симуляція}

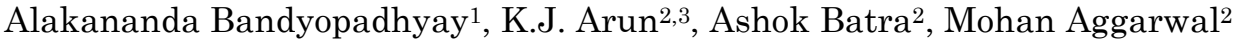 \\ 1 Department of Electrical Engineering \& Computer Science, Alabama A\&M University, 35762 Alabama, USA \\ 2 Department of Physics, Chemistry, and Mathematics, Alabama A\&M University Normal, 35762 Alabama, USA \\ ${ }^{3}$ Department of Physics, Sree Kerala Varma College, Thrissur, 680011 Kerala, India
}

\begin{abstract}
Чутливість та ефективність роботи інтегрованого піроелектричного інфрачервоного детектора залежать не тільки від характеристик матеріалу сенсорного елемента, а й від теплових характеристик всіеї конструкції детектора, включаючи супутню електроніку. Таким чином, ми отримали функцію теплопередачі, вирішивши одновимірне рівняння теплової дифузії для $n$-шарової структури з одним елементом, з якого можна отримати, передбачити та оптимізувати ефективність детекторної структури з будь-якою кількістю шарів. Різні конфігурації датчика з одним елементом на гнучкій підкладщі 3 полііміду та піроелектричні і теплові параметри модифікованої плівки титанату стронцію свинщю (PST) використовуються для прогнозування поточної чутливості інтегрованої детекторної системи. Отримані результати порівнюються з результатами для кремнієвої підкладки і виявляються привабливими для розробки гнучкої тонкоплівкової детекторної системи.
\end{abstract}

Ключові слова: Піроелектричний, Інфрачервоні детектори, PST, Поліімід, MatLab версії 9.0. 